NBER WORKING PAPER SERIES

\title{
VERTICAL PRODUCTION NETWORKS \\ IN MULTINATIONAL FIRMS
}

\author{
Gordon H. Hanson \\ Raymond J. Mataloni, Jr. \\ Matthew J. Slaughter \\ Working Paper 9723 \\ http://www.nber.org/papers/w9723
NATIONAL BUREAU OF ECONOMIC RESEARCH 1050 Massachusetts Avenue
Cambridge, MA 02138 \\ May 2003
}

For assistance with data we thank Bruce Blonigen, Fritz Foley, Jon Haveman, and James Rauch. For helpful comments we thank David Belli, Lael Brainard, Fritz Foley, Ann Harrison, Jim Hines, Ned Howenstine, Tom Hubbard, Jorg Mayer, Peter Merrill, Richard Sansing, Doug Staiger, Adrian Tschoegl, Obie Whichard, William Zeile and conference and seminar participants at the American Economics Association, the Brookings Institution and International Tax Policy Forum, Erasmus University, the Federal Reserve Board, the London School of Economics, the National Bureau of Economic Research, Stanford University, the U.S. Bureau of Economic Analysis, University of Chicago Graduate School of Business, the Wharton School, and Yale University. For financial support Hanson and Slaughter gratefully acknowledge the National Science Foundation. Views expressed in this paper are those of the authors and do not necessarily reflect those of the Bureau of Economic Analysis. The statistical analysis of firm-level data on U.S. multinational companies reported in this study was conducted at the International Investment Division, U.S. Bureau of Economic Analysis, under arrangements that maintained legal confidentiality requirements. The views expressed herein are those of the authors and not necessarily those of the National Bureau of Economic Research.

C2003 by Gordon H. Hanson, Raymond J. Mataloni, and Matthew J. Slaughter. All rights reserved. Short sections of text not to exceed two paragraphs, may be quoted without explicit permission provided that full credit including $($ ) notice, is given to the source. 
Vertical Production Networks in Multinational Firms

Gordon H. Hanson, Raymond J. Mataloni, and Matthew J. Slaughter

NBER Working Paper No. 9723

May 2003

JEL No. F2, F1, L1

\section{$\underline{\text { ABSTRACT }}$}

In recent decades, growth of overall world trade has been driven in large part by the rapid growth of trade in intermediate inputs. Much of this input trade involves multinational firms locating input processing in their foreign affiliates, thereby creating global vertical production networks. In this paper, we use firm-level data on U.S. multinationals to examine trade in intermediate inputs for further processing between parent firms and their foreign affiliates. We estimate affiliate demand for imported inputs as a function of host-country and industry trade costs, factor prices, and other variables. Among our main findings are that demand for imported inputs is higher when affiliates face lower trade costs, lower wages for less-skilled labor (both in absolute terms and relative to wages for more-skilled labor), and lower corporate income tax rates. These results contrast with many findings in previous research.

Gordon H. Hanson

IR/PS

University of California, San Diego

9500 Gilman Drive

La Jolla, CA 92093-0519

and NBER

gohanson@ucsd.edu

Matthew J. Slaughter

Tuck School of Business

Dartmouth College

100 Tuck Hall

Hanover, NH 03755

and NBER

matthew.slaughter@dartmouth.edu
Raymond J. Mataloni, Jr.

U.S. Department of Commerce

Bureau of Economic Analysis

Mail Stop: BE-50

1441 L Street, NW

Washington, DC 20230

raymond.mataloni@bea.gov 


\section{Introduction}

History has seen multiple waves of "globalization." On many measures, recent decades constitute another such wave. All waves are not the same, however. Two novel features of the current process of globalization are increased trade in intermediate inputs and increased flows of foreign direct investment (FDI).

Intermediate inputs play an important role in the recent growth of world trade. Yeats (2001) finds that trade in inputs has grown much faster than trade in final goods, and he estimates that intermediates now account for $30 \%$ of world trade in manufactures. ${ }^{1}$ Hummels, Ishii, and Yi (2001) identify vertical specialization, which they define as production arrangements in which firms make final goods via multiple stages located in multiple countries, as an important aspect of overall input trade. ${ }^{2}$ They calculate that from 1970 to 1990 , the increase in exports associated with vertical specialization accounted for one-third of world export growth. During the early $20^{\text {th }}$ century, in contrast, inputs played only a small role in U.S. trade (Feenstra, 1998).

As for FDI, the rising share of multinational enterprises in overall production helps distinguish the current phase of globalization from previous episodes (Bordo, Eichengreen, and Irwin, 1999). Multinationals now mediate a large fraction of world trade. In the United States, they account for over half of total exports (Slaughter, 2000). Within manufacturing, the majority of these exports are of intermediates. In 1999, 93\% of exports by U.S. parent firms to their foreign manufacturing affiliates were inputs for further processing (U.S. BEA, 2002).

Parent-to-affiliate input trade is one element of what we shall call vertical production networks in multinationals. The term "vertical" captures two key features of these networks: (i) within these firms the parent and each affiliate performs a narrow rather than broad range of

\footnotetext{
${ }^{1}$ See also Campa and Goldberg (1997).
} 
production activities and (ii) the parent and its affiliates are linked by intra-firm flows of inputs and outputs. In the jargon of trade theory, vertical production networks are a form of "vertical FDI" through which multinationals spread across different locations the different activities that they perform, such as $\mathrm{R} \& \mathrm{D}$, input production, and input processing.

To fix ideas on vertical production networks, consider the well-known example of automobile production in North American Free Trade Agreement (NAFTA) countries. Canadian and Mexican auto plants have extensive intra-firm links with their U.S. counterparts, mediated by large flows of inputs across borders. It is estimated that every day $\$ 250$ million in autos and auto parts crosses the Ambassador Bridge that connects Detroit, Michigan with Windsor, Ontario. When the U.S. government closed this bridge and other entry points after the terrorist attacks of September 11, 2001, several NAFTA auto plants had to shut down within 48 hours because of input shortages (Council on Foreign Relations, 2002).

The extent of vertical production networks, however, varies across both countries and industries. In Brazil, which is protected by common external tariffs under the Common Market of the Southern Cone (Mercosur), multinational auto manufacturers tend to set up integrated production facilities that engage in relatively little international trade with their parent firms or with other affiliates of the same parent (Hanson, 2001). In many countries, other industries, such as chemicals and non-metallic minerals, also exhibit high degrees of integration.

What accounts for this variation? Theories we discuss below offer several explanations for vertical production networks, including cross-country and/or cross-industry differences in trade costs, factor prices, and the technological separability of production. While there is anecdotal evidence to support these theories, little work goes beyond documenting broad facts to provide a

\footnotetext{
2 This phenomenon has been given various names, including de-localization, disintegration of production, fragmentation, global production sharing, foreign outsourcing, and slicing up the value chain. See Feenstra and Hanson (2002) for a discussion.
} 
theoretically informed, micro-level empirical analysis of the importance of these explanations. In this paper we provide such an analysis using firm-level data on U.S. multinationals.

These data come from legally mandated confidential surveys conducted by the U.S. Bureau of Economic Analysis (BEA) of all U.S. multinationals. For majority-owned foreign affiliates in manufacturing in 1994, we have a direct measure of input flows associated with vertical production networks: imports from U.S. parent firms (and other U.S. entities) of intermediate inputs for further processing. ${ }^{3}$ We use a standard cost-minimization framework to derive the demand for imported inputs by foreign affiliates, and we then estimate the sensitivity of this demand to host-country/industry trade costs, factor prices, taxes, and other variables suggested by theory. Our estimation combines data from the BEA surveys with data from outside sources on host-country policies and characteristics. Having comprehensive data on the foreign activities of U.S. multinationals allows us to address several important estimation issues, such as the absence of data on transaction prices between parent firms and their affiliates.

Our empirical analysis yields a number of results on the determinants of vertical production networks in multinational firms. One is that imports of intermediate inputs are strongly negatively correlated with trade costs facing affiliates. Our preferred estimates, which appear robust to a range of estimation choices, imply an elasticity well over unity: a $1 \%$ fall in trade costs leads to a $2 \%-4 \%$ increase in the quantity of imported intermediate inputs for further processing. This responsiveness of vertical production networks to trade costs appears consistent with recent theoretical work (e.g., Yi, 2003) in which small changes in tariffs produce large changes in input trade. Previous empirical work on multinationals (e.g., Carr, Markusen, and

\footnotetext{
3 We examine one component of vertical production networks: the processing by foreign affiliates of intermediate inputs imported from their U.S. parents. Unfortunately, the BEA data do not track production networks involving arm's-length interfirm transactions. We do not observe processing trade between U.S. parents and foreign entities that they do not own. Thus, our data are not well suited to consider questions of optimal firm boundaries.
} 
Maskus, 2001), finds that the scale of foreign-affiliate operations is greater the higher are hostcountry tariffs and transportation costs. These results have been interpreted to mean that higher trade costs encourage FDI. When a multinational intends to sell goods in a particular foreign market, higher trade costs may indeed encourage locating production in that market. But our results suggest that when multinationals serve various foreign markets via vertical production networks, higher trade costs may deter FDI instead.

A second finding is that vertical production networks are sensitive to labor costs. Importedinput demand is decreasing in host-country wages for less-skilled workers and increasing in hostcountry wages for more-skilled workers. Here again, our results contrast with previous empirical literature (e.g., Brainard, 1997), which tends to find that, if anything, U.S. firms prefer to locate in high-wage countries. We find that foreign affiliates do more processing of imports in countries with relatively cheap less-skilled labor.

A third finding is that vertical production networks also depend on other host-country policies and characteristics. Imported-input demand is higher in host countries with exportprocessing zones, and is decreasing in host-country market size and corporate tax rates. While many studies document how taxes affect aggregate FDI (Hines, 2001), there is little work on how taxes or other host-countries policies affect the composition of FDI.

Our paper has four additional sections. In section 2 we discuss related research. In section 3 we present our empirical framework. In section 4 we discuss the data and present summary statistics. In section 5 we report our estimation results. And in section 6 we conclude.

\section{Related Research}

Our work is relevant to several bodies of literature on trade in intermediate inputs and multinational enterprises. The first is research on the impact of declining trade barriers. Many 
studies conjecture that falling trade costs contribute to vertical production networks. In an important recent paper, Yi (2003) argues that standard models of trade in final goods cannot account for how the modest observed declines in trade barriers could have produced the dramatic observed growth in world trade. Yi shows theoretically how trade in inputs allows declining trade barriers to trigger magnified decreases in production costs and thus dramatic increases in total trade flows. We examine (and find support for) this hypothesis by estimating the sensitivity of demand for imported intermediate inputs to trade costs.

The second body of literature to which our paper relates is empirical work on theories of multinational firms. Theory tends to view multinationals as the result of either horizontal expansion (in which firms save on trade costs associated with exporting by setting up foreign facilities whose range of production activities mirrors the operations they perform at home) or vertical expansion (in which firms fragment different production stages across different countries to arbitrage international differences in factor prices). ${ }^{4}$ Casual evidence suggests that horizontal FDI is the dominant strategy of U.S. multinationals. In 1998, OECD countries accounted for $76.6 \%$ of sales by affiliates of U.S. firms (Hanson, et al, 2001), giving the impression that market size (and not wage levels) is the host-country feature U.S. multinationals care most about.

Several recent studies test theories of FDI rigorously by using aggregate data on the total sales of U.S. foreign affiliates by country (or by country and industry). ${ }^{5}$ Most studies find that affiliate sales are higher in larger countries and in countries with higher tariffs and transport costs on U.S. goods, but not in countries with larger skill differences relative to the United States. These results are interpreted as evidence in favor of horizontal FDI and against vertical FDI.

\footnotetext{
4 On the former, see Markusen (2002) and Markusen and Venables (2000). On the latter, see Helpman (1984), Helpman and Krugman (1985), and Yeaple (2001). Ekholm, Forslid, and Markusen (2003) model "export platform" FDI, in which most affiliate output is exported out of the host country, an affiliate activity that shares both horizontal and vertical features.
} 
In our work, we do not treat horizontal and vertical FDI as mutually exclusive options. The same U.S. multinational might choose to operate in France an integrated plant to produce for the domestic market and might also choose to operate in China a specialized factory to assemble components manufactured by the U.S. parent. The French affiliate would be the result of horizontal FDI, the Chinese affiliate vertical FDI. Having firm-level data allows us to examine the factors that determine where different affiliates fall in a continuum with pure horizontal FDI at one extreme and pure vertical FDI at the other extreme. This goes beyond previous research by addressing the factors that shape the composition of production inside affiliates.

Existing work most closely related to ours includes Feinberg and Keane (2001), who examine the determinants of bilateral trade between U.S. parents and their Canadian affiliates over the period 1983-1992. They find that affiliate total imports from U.S. parents have little association with Canadian tariffs, though in the reverse direction they find that parent imports from Canadian affiliates negatively vary with Canadian tariffs. They also find that import flows have no correlation with Canadian or U.S. wages. Our work differs from theirs by focusing on trade in intermediate inputs, rather than total trade, and by analyzing affiliates worldwide, rather than just in Canada. Their finding of no wage impacts on parent-affiliate trade, for example, might simply reflect small Canadian-U.S. wage differences. In support of this idea, Hanson, Mataloni, and Slaughter (2001) and Borga and Zeile (2002) find that foreign affiliates of U.S. multinationals engage in relatively more intra-firm trade in low-wage countries. ${ }^{6}$

Other bodies of literature to which our work relates includes studies on the labor-market consequences of foreign outsourcing (see the survey in Feenstra and Hanson, 2002), empirical

\footnotetext{
5 See Brainard (1997); Markusen and Maskus (1999); Blonigen, Davies, and Head (2002); and Helpman, Melitz, and Yeaple (2003). Yeaple (2001) finds the impact of host-country education on affiliate sales to be weaker for less-skill-intensive industries, suggesting that multinationals in these industries prefer less-skill-abundant countries.
} 
studies on the magnitude of spillovers associated with FDI (e.g., Haskel, Pereira, and Slaughter, 2001), and recent theoretical work on how trade costs shape ownership and outsourcing decisions in multinational firms (Grossman and Helpman, 2002a,b).

\section{An Empirical Model}

In this section, we develop an empirical framework for how U.S. multinationals organize the operations of their foreign affiliates. Consistent with our data, we focus on affiliate operations at a given point in time (see note 7). We assume that U.S. parent firms have previously chosen in which countries to locate affiliates. The remaining decision is over which production activities affiliates should perform. For simplicity, consider two production stages: input manufacturing and input processing. Input manufacturing often involves producing sophisticated componentry, and so is likely to be relatively skill and capital intensive. Input processing often is limited to assembly, and so is likely to be relatively labor intensive.

Consider two alternative strategies for FDI. A vertical production network would have foreign affiliates import inputs from their U.S. parents, process these inputs into final products, and then ship these processed inputs on to destination markets. By locating labor-intensive input processing abroad and capital-intensive input production in the United States, this strategy could allow the multinational to take advantage of international differences in factor prices. But shipping inputs between countries results in high transport costs. An alternative strategy would have foreign affiliates both produce and process inputs. In this case, the firm replicates abroad the production activities of the U.S. parent. This strategy minimizes transport costs, since there is no need for affiliates to import inputs, but it also prevents the multinational from taking full

\footnotetext{
6 For related evidence, see Kumar (1994) and Barba Navaretti, Haaland, and Venables (2002). Again using aggregated data, Shatz (2000) and Markusen and Maskus (2001) study the exporting behavior of U.S. multinationals.
} 
advantage of factor-price differences across countries. In reality, firms may choose a strategy between the two extremes just described, with this choice depending on trade costs, labor costs, and on other host-country and industry characteristics.

\subsection{Empirical Specification}

Consider a foreign affiliate of a U.S. parent firm. Let the cost function for the affiliate be $\mathrm{C}(\mathbf{w}, \mathrm{Y})$. Here, $\mathrm{Y}$ represents affiliate total output and $\mathbf{w}$ is a vector of factor prices facing the affiliate, including wage rates for labor used in input production, wage rates for labor used in input processing, the rental price of capital, the price of manufacturing inputs imported from the parent, and the price of services imported from the parent.

There are two items to note about this cost structure. The first is its static nature. This follows from our data being a cross-section and not a panel of affiliates. ${ }^{7}$ The second is that we assume the affiliate cost function is separable from that of the U.S. parent. This allows us to examine activity choices of affiliates in isolation, and is appropriate so long as input production and input processing are technologically separable activities and affiliates face output prices set on the world market. In the estimation, we allow for the possibility that within a multi-affiliate firm, the same affiliates of a given U.S. parent use similar production technology and face common prices for inputs or services imported from the parent.

To derive an estimating equation, we need to select a functional form for costs. A convenient choice is the translog form, which Diewert (1974) introduced and Kohli $(1978,1991)$ used initially in the international-trade literature. In our case, this function can be written as

\footnotetext{
7 Data on input trade between affiliates and their U.S. parents do exist for a few other BEA "benchmark" years (e.g., 1989). We have not added these years to our sample because for earlier years we lack corresponding non-BEA data on key regression variables. Adding additional years would probably not greatly enhance the estimation. Over short to medium time horizons, the primary variation in key variables including wages, tariffs, and tax rates is across countries and not time. Having additional years of data would allow us to control for affiliate fixed effects, but this would come at the potential cost of losing much of the
} 


$$
\begin{aligned}
\ln C= & \alpha_{0}+\sum_{h=1}^{\mathrm{H}} \alpha_{\mathrm{h}} \ln \mathrm{w}^{\mathrm{h}}+\frac{1}{2} \sum_{\mathrm{h}=1 \mathrm{j}=1}^{\mathrm{H}} \sum_{\mathrm{h}=1}^{\mathrm{H}} \gamma_{\mathrm{hj}} \ln \mathrm{w}^{\mathrm{h}} \ln \mathrm{w}^{\mathrm{j}} \\
& +\beta_{\mathrm{y}} \ln \mathrm{Y}+\frac{1}{2} \beta_{\mathrm{yy}} \ln \mathrm{Y}^{2}+\sum_{\mathrm{h}=1}^{\mathrm{H}} \phi_{\mathrm{hy}} \ln \mathrm{w}^{\mathrm{h}} \ln \mathrm{Y}
\end{aligned}
$$

where $\mathrm{w}^{\mathrm{h}}$ denotes the prices of the optimally chosen variable inputs $\mathrm{h}=1, \ldots, \mathrm{H}$.

The usefulness of the translog function becomes evident when we compute first derivatives, $\partial \operatorname{lnC} / \partial \ln w^{h}=\left(\partial C / \partial w^{h}\right)\left(w^{h} / C\right)$. By Shepard's Lemma, $\partial C / \partial w^{h}$ equals the demand for input $h$. It follows that $\left(\partial \mathrm{C} / \partial \mathrm{w}^{\mathrm{h}}\right)\left(\mathrm{w}^{\mathrm{h}} / \mathrm{C}\right)$, the elasticity of total cost with respect to price h, equals the share of factor $\mathrm{h}$ in total costs, which we denote by the cost-share $\mathrm{s}^{\mathrm{h}}$. Differentiating equation (1) with respect to $\ln w^{\mathrm{h}}$ yields the following expression,

$$
\mathrm{s}^{\mathrm{h}}=\alpha_{\mathrm{h}}+\sum_{\mathrm{j}=1}^{\mathrm{H}} \gamma_{\mathrm{hj}} \ln \mathrm{w}^{\mathrm{j}}+\phi_{\text {hy }} \ln \mathrm{Y}
$$

for $\mathrm{h}=1, \ldots, \mathrm{H} .^{8} \quad$ The expression in (2) relates the demand for input $\mathrm{h}$, measured as its share in total costs, to prices of variable inputs and the level of output.

These cost shares are the basis for our empirical work. We estimate the cost-share equation for the key input of imported intermediates for further processing, and we denote the share of imported intermediate inputs in total costs by $\mathrm{s}^{\mathrm{m}} \cdot{ }^{9}$ We interpret affiliates with higher values of $\mathrm{s}^{\mathrm{m}}$ to be affiliates that are more specialized in the activity of processing parent-produced inputs.

systematic variation in our regressors. Even with just a single year of data, we are able to control for parent-by-industry fixed effects. This, as we discuss, allows us to address what appear to be the more important estimation issues - e.g., measuring prices. 8 In the event there are constant returns to scale, $\varphi_{\text {hy }}=0$. We find evidence consistent with affiliate technology being constant returns. That affiliates exhibit constant returns in no way implies that parents do as well (given the importance of R\&D and other fixed costs in parent operations, we expect their technology to exhibit increasing returns).

${ }^{9}$ Given data limitations, we cannot estimate cost shares for other inputs. BEA data only report aggregate employment of capital and labor for an affiliate. When an affiliate, say, hires labor we do not know whether it is to produce inputs, process inputs, or both. By estimating a single cost-share equation, we cannot impose cross-equation parameter restrictions implied by the symmetry of cross-price derivatives and by the fact that the cost shares sum to one. 
Accordingly, we interpret our estimates of the $\mathrm{s}^{\mathrm{m}}$ equation to inform about the determinants of vertical production networks in multinational firms. ${ }^{10}$

Given our definition of $\mathrm{s}^{\mathrm{m}}$, an estimating equation for affiliate a in industry $\mathrm{i}$ belonging to U.S. parent $\mathrm{p}$ and located in host-country $\mathrm{c}$ is,

$$
\mathrm{s}_{\text {aipc }}^{\mathrm{m}}=\alpha_{\mathrm{ip}}+\gamma_{\mathrm{ms}} \ln \mathrm{w}_{\mathrm{c}}^{\mathrm{s}}+\gamma_{\mathrm{mu}} \ln \mathrm{w}_{\mathrm{c}}^{\mathrm{u}}+\gamma_{\mathrm{mk}} \ln \mathrm{r}_{\mathrm{aipc}}+\gamma_{\mathrm{mm}} \ln \mathrm{p}_{\mathrm{ipc}}^{\mathrm{m}}+\gamma_{\mathrm{mo}} \ln \mathrm{p}_{\mathrm{ipc}}^{\mathrm{hq}}+\phi_{\mathrm{my}} \ln \mathrm{Y}_{\mathrm{aipc}}+\varepsilon_{\text {aipc }}^{\mathrm{m}}
$$

where $\alpha_{\mathrm{ip}}$ is a parent- and industry-specific constant term; $\mathrm{w}_{\mathrm{c}}^{\mathrm{s}}$ is the price of skilled labor in country $c ; \mathrm{w}_{\mathrm{c}}^{\mathrm{u}}$ is the price of unskilled labor in $\mathrm{c} ; \mathrm{r}_{\mathrm{aipc}}$ is the affiliate's rental price of capital; $\mathrm{p}_{\mathrm{ipc}}^{\mathrm{m}}$ $\left(p_{i p c}^{\text {hq }}\right)$ is the price of intermediate inputs (headquarter services) imported from parent $p$ in industry $\mathrm{i}$ and country $\mathrm{c}$; $\mathrm{Y}_{\text {aipc }}$ is affiliate output; and $\varepsilon_{\text {aipc }}^{\mathrm{m}}$ is a disturbance term.

After estimating equation (3) it is straightforward to calculate the cross- and own-price elasticities of factor demand. The own-price elasticity of demand for factor $\mathrm{m}$, imported intermediate inputs, is given by,

$$
\operatorname{PED}_{\mathrm{mm}}=\frac{\gamma_{\mathrm{mm}}+\mathrm{s}^{\mathrm{m}}\left(\mathrm{s}^{\mathrm{m}}-1\right)}{\mathrm{s}^{\mathrm{m}}}
$$

where $\gamma_{\mathrm{mm}}$ is a parameter to be estimated and $\mathrm{s}$ is calculated at the mean for the regression sample. The cross-price elasticity of demand between inputs $\mathrm{m}$ and $\mathrm{h}$ is given by,

$$
\mathrm{PED}_{\mathrm{mh}}=\frac{\gamma_{\mathrm{mh}}+\mathrm{s}^{\mathrm{m}} \mathrm{s}^{\mathrm{h}}}{\mathrm{s}^{\mathrm{m}}}
$$

\footnotetext{
10 Strictly speaking, our interpretation of $\mathrm{s}^{\mathrm{m}}$ requires the assumption that affiliates all sell the same output in terms of the location on the value-added chain. Otherwise, differences in cost shares could reflect differences in affiliate location along the chain of production, independent of the range of activities affiliates perform. The BEA data contain no such information on output stages, as is the case for many similar micro-level data sets. See Adelman (1955) for a discussion of these measurement issues.
} 
An advantage of the translog framework is that it does not impose restrictions on the pair-wise elasticities of substitution between inputs (as do Cobb-Douglas or CES).

\subsection{Estimation Issues}

Several important estimation issues merit attention. One is that we do not have data on $\mathrm{p}_{\mathrm{ipc}}^{\mathrm{m}}$ or $\mathrm{p}_{\mathrm{ipc}}^{\mathrm{hq}}$, the transaction prices that affiliates pay for inputs and services they import from their parents. This limitation is hardly surprising. There is little price data for trade flows anywhere, let alone for individual businesses operating in hundreds of countries and industries. We can address this problem by exploiting the structure of the BEA data; specifically, the fact that most foreign affiliates share a U.S. parent with at least one other affiliate.

Suppose that $\mathrm{p}_{\mathrm{ipc}}^{\mathrm{m}}$ can be expressed in log terms as the sum of two parts: the f.o.b. price in the United States for that import, and a host-country wedge between that U.S. price and $\mathrm{p}_{\mathrm{ipc}}^{\mathrm{m}}$ that is due to trade costs. For example, a U.S. parent that manufactures electrical appliances may obtain tungsten in the United States for all its light-bulb affiliates abroad, but different affiliates may pay different prices based on the trade costs they face. In our analysis, we model this price wedge as the sum of import tariffs and transport costs, allowing us to write $\mathrm{p}_{\mathrm{ipc}}^{\mathrm{m}}$ as,

$$
\ln p_{\text {ipc }}^{m}=\ln p_{i p}^{m}+\ln \left(1+\tau_{i c}+f_{i c}\right)
$$

where $\mathrm{p}_{\mathrm{ip}}^{\mathrm{m}}$ is the f.o.b. price of the input in the United States, $\tau_{\mathrm{ic}}$ is the ad valorem tariff rate that country c levies on imports in industry $\mathrm{i}$, and $\mathrm{f}_{\mathrm{ic}}$ is the ad valorem freight rate on imports from the United States in country c for industry i.

We have data on trade costs but not on $\mathrm{p}_{\mathrm{ip}}^{\mathrm{m}}$. We do, however, observe the activities of multiple affiliates that operate in the same industry and that share the same parent. If the parent 
charges its affiliates in the same industry the same f.o.b. price for inputs, then trade costs will be the only source of variation in $\mathrm{p}_{\mathrm{ipc}}^{\mathrm{m}}$ across affiliates in the same industry belonging to the same parent. We can then measure $\mathrm{p}_{\mathrm{ipc}}^{\mathrm{m}}$ in two parts: (a) a full set of parent-by-industry dummy variables, $\widetilde{\alpha}_{i p}=\alpha_{i p}+\gamma_{m m} \ln p_{i p}^{m}$, which captures industry-and-parent specific technology, $\alpha_{i p}$, and the unobservable f.o.b. price, $\mathrm{p}_{\mathrm{ip}}^{\mathrm{m}}$; and (b) host-country trade costs, which we measure using data on host-country and industry tariffs, non-tariff barriers, and freight rates. ${ }^{11}$

Allowing for parent-by-industry fixed effects, rather than just parent effects, allows for the fact that many multinationals are multi-product firms whose affiliates span diverse industries. Thus, a parent firm's light-bulb affiliates can face different imported-input prices from its refrigerator affiliates. These parent-by-industry controls also address differences in the extent of vertical production networks due to technological primitives or firm business practices (e.g., networks may be less feasible in food industries with highly perishable inputs).

By the same logic, we also control for unobservable headquarter-service prices, $\mathrm{p}_{\mathrm{ipc}}^{\mathrm{hq}}$. The parent-by-industry controls, $\widetilde{\alpha}_{i p}$, capture any unobserved components of service prices that parents charge to all affiliates in the same industry; measures of trade costs capture countryand/or industry-specific components. Affiliates may import from parents a wide range of headquarter services, such as use of patents, copyrights, and trademarks, analysis of market conditions, or advice about management strategy. Parents may receive payment for these services through either fees or repatriated earnings. The price parents charge may vary across affiliates due to transport costs (e.g., more-remote affiliates may be more costly to service), in a manner similar to imported manufacturing inputs. This price may also vary across affiliates due

\footnotetext{
${ }^{11}$ In host countries, multinationals are sometimes accused of attempting to influence trade policy to their advantage. Given this
} 
to host-country corporate income taxes (e.g., higher tax rates may make repatriated earnings less attractive), and so we include this variable as a regressor.

An important aspect of measuring both $\mathrm{p}_{\mathrm{ipc}}^{\mathrm{m}}$ and $\mathrm{p}_{\mathrm{ipc}}^{\mathrm{hq}}$ is transfer pricing. It is commonly asserted that multinationals price intra-firm transactions such that firm-wide pre-tax profits accrue to affiliates in low-tax jurisdictions. ${ }^{12}$ We have no direct data on transfer pricing, but our treatment of $\mathrm{p}_{\mathrm{ipc}}^{\mathrm{m}}$ and $\mathrm{p}_{\mathrm{ipc}}^{\mathrm{hq}}$ summarized in (6) should control for at least some of any unobservable transfer-pricing motives. The parent-by-industry controls capture differences in the average propensity to transfer price across U.S. parents, which may result from variation in their global foreign-tax-credit status with the Internal Revenue Service. And the inclusion of corporate income tax rates controls for transfer-pricing motivations that vary across host-countries.

A second estimation issue is that we do not observe prices for any intermediate inputs that affiliates may purchase locally. In principle, the price for local inputs should be an additional regressor in equation (3). In practice, these prices may be well captured by our just-discussed measures for $\mathrm{p}_{\mathrm{ipc}}^{\mathrm{m}}$ and $\mathrm{p}_{\mathrm{ipc}}^{\mathrm{hq}}$. If local input prices are set on the world market, and so equal to world input prices plus trade costs, then including as regressors parent-by-industry dummy variables and trade costs controls for their presence.

A third estimation issue involves the regressand. In our data, the dependent variable $\mathrm{s}_{\mathrm{aipc}}^{\mathrm{m}}$ takes a value of zero for many affiliates. This may be due to the technological infeasibility of separating input production and processing, which would result in an affiliate strategy of integrating both activities. One approach to this problem would be to include in (3) measures of the technological separability of production as regressors and then estimate (3) as a Tobit.

possibility, in the estimation we allow for the possible endogeneity of host-country industry tariffs. 
Below, we experiment with one possible industry-level proxy. The parent-by-industry dummy variables could also proxy for these measures, but the presence of a large number of unobserved fixed effects complicates use of the Tobit. With few observations per indicator variable category (i.e., small numbers of affiliates of the same parent firm and in the same industry), there is the risk that Tobit estimates of parameter coefficients would be inconsistent (Wooldridge, 2002).

Instead, we address zero observations in the dependent variable in two ways. First, we drop from the sample affiliates in industries in which imports of inputs for further processing are rare. ${ }^{13}$ The excluded industries - e.g., food processing, pulp and paper, newspapers, soap and cleansers-appear to be primarily ones in which either there is a single stage of production or technology or transport costs make it prohibitively expensive to geographically separate input production and input processing. Second, we check the consistency of our OLS estimates of (3) by using a Tobit with a more-aggregate set of indicator variable categories. Fewer parentindustry combinations increase the observations per category and thus improve consistency.

A fourth estimation issue is how to measure wages. In equation (3) wages are assumed to vary only across countries. This would be the case if affiliates are price-takers in labor markets and if labor markets are national in scope. In practice, wages may vary across other dimensions as well. For instance, wages may vary by industry, consistent with evidence on inter-industry wage differentials, and particular multinationals may offer wage premia to attract more able workers. In the empirical analysis, we use as a baseline wages at the country level and experiment with measures at the industry or affiliate level.

A final estimation issue is that there may be country-level policies and characteristics that influence how foreign affiliates organize their activities. To control for this possibility, we

\footnotetext{
12 See Sansing (1999) for an overview of U.S. tax code regarding multinational transfer pricing and for a theoretical analysis of transfer-pricing rules. For empirical evidence on transfer pricing, see Clausing (2001) and Grubert and Mutti (1991).
} 
include as additional regressors measures of host-country investment and exchange-rate policies and of the quality of its financial, legal, and political institutions.

\subsection{Summary of Estimation Strategy}

To summarize our estimation strategy, our goal is to explain the variation in imported intermediate inputs across foreign affiliates that are in the same industry and that share the same U.S. parent. In controlling for parent-by-industry fixed effects, we identify the responsiveness of processing imported inputs to trade costs, wages, tax rates, and other factors by exploiting the cross-country variation in these variables. Our baseline estimating equation is:

$$
\begin{aligned}
\mathrm{s}_{\text {aipc }}^{\mathrm{m}}=\widetilde{\alpha}_{\mathrm{ip}} & +\gamma_{\mathrm{ms}} \ln \mathrm{w}_{\mathrm{c}}^{\mathrm{s}}+\gamma_{\mathrm{mu}} \ln \mathrm{w}_{\mathrm{c}}^{\mathrm{u}}+\gamma_{\mathrm{mk}} \ln \mathrm{r}_{\text {aipc }}+\gamma_{\mathrm{mm}} \ln \left(1+\tau_{\mathrm{ic}}+\mathrm{f}_{\mathrm{ic}}\right) \\
& +\gamma_{\mathrm{mt}} \ln \left(1-\mathrm{t}_{\mathrm{c}}\right)+\phi_{\mathrm{my}} \ln \mathrm{Y}_{\text {aipc }}+\beta \mathrm{X}_{\mathrm{ic}}+\varepsilon_{\text {aipc }}^{\mathrm{m}}
\end{aligned}
$$

where, among the new variables relative to (3), $\tau_{\mathrm{ic}}$ is the host-country industry ad valorem tariff rate; $f_{i c}$ is the host-country industry ad valorem freight rate; $t_{c}$ is the host-country corporate tax rate; and $\mathrm{X}_{\mathrm{ic}}$ are measures of other host-country and/or industry policies and characteristics. Coefficient estimates from (7) will thus provide insight about the determinants of vertical production networks in multinational firms.

\section{Data Description and Summary Statistics}

\subsection{Data Sources}

The primary data for this project are for the operations of U.S. multinationals, both of their U.S.-based parents and their foreign affiliates, as collected by the BEA in legally mandated confidential surveys. An appendix describes in detail these and related non-BEA data.

13 The cutoff we apply is an industry mean of imported inputs for further processing as a share of total sales of greater than $5 \%$. 
We use BEA data from its 1994 "benchmark" survey, which covers the entire population of U.S. multinationals in that year. Less data are collected for minority-owned affiliates, so we use the population of majority-owned affiliates in manufacturing, of which there were 6,955 in 1994 (out of 8,014 total manufacturing affiliates linked to 1,456 U.S. parent enterprises). This group of majority-owned affiliates spanned 54 manufacturing industries and 105 host countries; the related group of parents has a median of four affiliates (with a maximum of 146). Each affiliate is classified in a single industry of primary business based on the distribution of its sales across industries. Controlling for parent-industry fixed effects require us to exclude from the sample any affiliates that are the sole affiliate of a parent/industry.

For our regression analysis in equation (7), the dependent variable $s_{\text {aipc }}^{\mathrm{m}}$ is the share in total affiliate costs of imports for further processing from the United States (either from the U.S. parent or from another U.S. entity). ${ }^{14}$ Total economic costs are proxied by total accounting revenues plus inventory changes. We use two affiliate-level regressors: the capital rental rate and output. Rental rates are defined in the appendix. Total output is measured as BEA gross output (i.e., value added).

Turning to other regressors, we do not observe the true marginal prices for labor $\mathrm{w}_{\mathrm{c}}^{\mathrm{u}}$ and $\mathrm{w}_{\mathrm{c}}^{\mathrm{s}}$ facing each affiliate. We approximate marginal prices using wage unit values (compensation divided by employment) constructed from the United Nations' Industrial Statistics Database. As discussed in Section 3.2, for robustness we also try other wage measures.

Our primary trade-cost measures are tariffs, non-tariff barriers (NTBs), and transportation costs; all are bilateral for the host country vis a vis the United States and all vary by country and

\footnotetext{
14 The BEA tracks imported inputs from both from U.S. parents and from non-parent U.S. entities. Approximately $90-95 \%$ of imports from the United States by foreign affiliates of U.S. multinationals are from parent firms. Even where affiliate imports
} 
industry. Tariffs and NTBs come from the United Nations' TRAINS (Trade Analysis and Information System) database; transportation costs were generated from data files in Feenstra (1996). Tariffs and transport costs are ad valorem measures; NTB presence or absence is a categorical measure. Adjacency to the United States is an additional proxy for trade barriers. ${ }^{15}$

The remaining regressors capture additional host-country or industry policies and characteristics. From the University of Michigan World Tax Database, we have statutory corporate income tax rates that measure maximum marginal tax rates facing these businesses. To measure market size in the host-country, we use Hanson and Xiang's (2002) measure of market potential: national GDP plus a distance-weighted sum of GDP in neighboring countries. We include an indicator variable for English as the primary language. We also include several policy-related regressors: an indicator for the presence of export-processing zones (EPZs) and the value-added tax rate, both from PricewaterhouseCoopers; an indicator for whether the host country fixes the value of its currency to the U.S. dollar, from Shambaugh (2002); and measures of "economic freedom" and of "FDI openness," both from the Heritage Foundation and Wall Street Journal. Finally, we include materials purchases as a share of shipments in the United States for the affiliate's industry. This share may reflect the technological feasibility of an industry to organize its constituent activities into global production networks.

For the sample used to estimate our initial specifications of equation (7), Table 1 reports summary statistics for our regressand and several regressors. Relative to the full population of 6,955 majority-owned affiliates in manufacturing, our baseline sample is smaller due to missing host-country data. This baseline sample spans 39 industries (and is linked with 632 U.S. parents,

come from an entity other than the parent, the parent may still have arranged the transaction. As we discuss later, estimation results from using just imports from parents are nearly identical to those we report.

15 In unreported results, we included distance from the United States to the host-country as a regressor. After controlling for transportation costs and adjacency to the United States, distance was insignificant in most specifications. 
leading to 777 parent-industry effects) across 42 host countries. For the average affiliate in our sample, $11 \%$ of its total costs are accounted for by imports of intermediate inputs for further processing. Average host-country/industry import tariff and freight rates are each about 5\% (and these two variables have a sample correlation of 0.22 ). The mean less-skilled wage is just over half the value of the average more-skilled wage.

\subsection{Preliminary Evidence}

Before showing regression results, Table 2 first shows patterns of vertical production networks by broad industry and country groups in our data. Each cell of this table reports the mean share of imported inputs for further processing as a share of total revenues.

Input processing is most prominent in regions that have low trade costs and/or low labor costs vis a vis the United States. Mexico is the most obvious example. It is a low-wage country, and in 1994 it benefited not just from adjacency to the United States but from the start of lower trade barriers in the NAFTA. Canada is another example. While a high-wage country, it has even lower trade costs than Mexico. Canada's major production centers are located quite near industrial regions of the United States, and the Canadian-American Free Trade Agreement was signed in 1989. Input processing is also relatively common in East Asia. While distant from the United States, the region has moderate labor costs and open markets, at least in certain industries such as electronics. Consistent with theory, poor candidates for input processing include regions with high labor costs and moderate to high trade costs (OECD Europe, OECD Asia) and regions with relatively closed markets (Other Latin America, with the Mercosur countries of Argentina and Brazil; Other Asia, with India, Africa, and the Middle East).

Apart from regional patterns, certain industries appear to be good candidates for input processing. These include machinery, transportation equipment, and electronics, of which the 
largest sub-industry is computers. Several common features of these industries may make them amenable to global outsourcing. One is that production tends to involve distinct stages - design, component production, final assembly — that are physically separable. Firms need not perform these tasks in the same location, and so can locate different stages in different countries. Another feature is that these production stages exhibit different factor intensities, with design activities and component production being more skill-intensive and assembly activities being more laborintensive. To the extent that factor costs vary across countries, firms may have an incentive to locate labor-intensive activities in labor-abundant countries. ${ }^{16}$

In Section 1, we pointed out that the BEA does not track links in multinationals' vertical production networks other than affiliate imports of inputs for further processing from U.S. entities. In particular, BEA data do not measure affiliate exports of processed inputs to other affiliates or to their U.S. parent. Instead, the BEA reports only total affiliate exports. But if affiliates are exporting mainly processed intermediates, then our examination of affiliate imported inputs may be augmented by studying affiliate exports as well.

Table 3 offers some initial evidence on the export patterns of U.S. foreign affiliates. Constructed analogous to Table 2, each cell of this table reports affiliate exports to the United States as a share of total revenues. The pattern of export intensity across regions and industries is very similar to the pattern of imported-input intensity in the previous table. Export intensity is higher in countries with low trade costs and/or low wages relative to the United States. For our sample of affiliates, the correlation between affiliate imports of intermediate inputs from the U.S. as a share of revenue and affiliate exports to the U.S. as a share of revenue is 0.59 . Again, Table 3 measures total affiliate exports, not just affiliate exports of processed intermediate inputs, and

\footnotetext{
16 Note that Table 2 broadly accords with the introductory examples in Section 1 of vertical production networks. For example, Canadian and Mexican affiliates in transportation products have nearly half of their total sales accounted for imported
} 
so may be a noisy measure of trade flows within U.S. multinationals' vertical production networks. Still, the strong patterns of similarity between Tables 2 and 3 suggest that affiliates that are more oriented towards processing imported inputs are also more oriented towards production for export, as we would expect for affiliates that were part of such networks.

In the regression analysis, to which we turn next, we aim to uncover which factors drive the cross-affiliate variation just documented. The micro-data permit us to control for variation in the extent to which each parent chooses to operate vertical production networks.

\section{Estimation Results}

\subsection{Main Results for Imported-Input Demand}

Table 4 reports our baseline OLS estimates of equation (7). The dependent variable is imports for further processing as a share of affiliate revenues. Column 1 excludes additional controls, column 2 adds in a large number of such controls, and column 3 shows our preferred specification with a narrow set of controls chosen from the precisely estimated variables in column 2. All specifications include 777 parent-by-industry dummy variables.

There are three notable results in Table 4. First is the role of trade costs, which in this table are defined as in equation (7) as the sum of both ad valorem tariffs and freight rates. Imported intermediate inputs as a share of affiliate revenues are strongly negatively correlated with trade costs. Recall from Section 3.2 that trade costs are a potentially important determinant of the price of imported intermediate inputs that affiliates face. Our estimates suggest that affiliates do in fact respond to trade-cost-induced changes in imported-input prices. The coefficient estimate from our preferred specification in column 3 of Table 4 implies (from equation (4)) that the ownprice elasticity of demand for imported inputs is -3.28 (standard error of 0.71 ): a $1 \%$ fall in input 
prices due to a reduction in trade costs leads to a $3.3 \%$ increase in the quantity of imported intermediate inputs demanded by an affiliate. ${ }^{17}$

This sensitivity of input demand to trade costs appears consistent with Yi's (2003) model in which small changes in tariffs produce large changes in production costs and thus input trade. Again, Yi hypothesizes that actual tariff declines can explain actual trade growth only if their effects are amplified by trade in intermediate inputs. Our results accord with this theory.

This evidence also differs from previous empirical work on multinationals (e.g., Carr, et al, 2001), which finds that foreign-affiliate sales are higher the higher are host-country tariffs and transportation costs. Our evidence suggests a more-nuanced story, in which at least one important affiliate activity — processing imported intermediates—is inhibited, not encouraged, by higher trade barriers. The net impact of trade barriers on total FDI is likely to vary across affiliates with the scope and size of their different productive activities.

A second notable finding in Table 4 is the sensitivity of input processing to labor costs. Imported-input demand is decreasing in host-country wages for less-skilled workers and increasing in host-country wages for more-skilled workers, with all coefficients precisely estimated. The estimates from column 3 of Table 4 imply (from equation (5)) that the crossprice wage elasticities of demand for imported inputs are -0.32 (standard error of 0.09 ) for lessskilled labor and 0.36 (standard error of 0.09 ) for more-skilled labor. A $1 \%$ fall in less-skilled (more-skilled) wages leads to about a $1 / 3 \%$ increase (decrease) in imported intermediate inputs.

This responsiveness of input processing to wages is at odds with much of the earlier empirical work on multinationals that uses aggregate data (e.g., Brainard, 1997; Markusen and Maskus, 1999; Blonigen et al, 2002). Consistent with models of vertical FDI, we find that foreign affiliates do more processing of imports the lower are low-skilled wages relative to high-

17 Standard errors for elasticities are calculated using the Delta method. 
skilled wages. This accords with our intuition that imports for further processing and less-skilled labor are complements. That we find stronger evidence of vertical FDI than previous literature may be due to our use of micro-level data on foreign affiliates. Previous work, in contrast, uses data that aggregates not just across the activities of a given affiliate but also across all affiliates in a given industry and country. Our data suggest multinationals vary in the range of activities they perform and therefore may display both vertical and horizontal production characteristics.

The third notable result of Table 4 is the important role played by other host-country policies and characteristics. In our preferred column (3), imported-input demand is significantly (at the $10 \%$ level) higher in countries with lower corporate tax rates. This role for tax rates is consistent with evidence (e.g., Hanson, 2001) that many governments give tax breaks to foreign firms that engage in export processing within their borders - an activity that involves vertically specialized affiliates that import large amounts of inputs. Many studies have examined how taxes affect aggregate FDI (Hines, 2001), but not on how they affect the composition of FDI. ${ }^{18}$

Demand for imported intermediate inputs is higher for affiliates in Canada or Mexico, consistent with these countries enjoying lower trade costs with U.S. firms due to a combination of geographic proximity and preferential market access. Input demand is also significantly higher in host countries with EPZs. EPZs typically offer a range of incentives to promote exports, including tax holidays, expedited transit of goods through customs, and tariff breaks on imported equipment, which may induce firms to concentrate input processing in affiliates. ${ }^{19}$ Affiliate reliance on imported intermediate inputs is lower in countries situated in regions with

\footnotetext{
18 In Section 3.2 we discussed concerns about transfer pricing. If transfer pricing were dominating the variation in our data, then we would expect to see the opposite correlation between host-country tax rates and imported-input intensity. If multinationals were simply shifting profits to low-tax countries via input trade, then affiliates in these low-tax locations would be charged a below-market price for inputs. Holding affiliate output constant, this practice would generate low values for our dependent variable in low-tax locations, the opposite correlation from that actually revealed in our preferred specifications.
} 
larger market potential. This is consistent with horizontal theories of FDI, in which multinationals located in markets with larger local demand are more oriented towards integrated production (perhaps for local consumers) and less oriented towards operating via vertical production networks. Affiliate reliance on imported inputs is higher in host countries with higher levels of economic freedom. One interpretation is that poor governance of the economy is especially damaging to firms engaged in high levels of input importing and exporting.

The remaining regressors in Table 4 have generally insignificant coefficient estimates. Though insignificant, the estimates for NTBs are puzzling: imported intermediates as a share of affiliate revenues are positively correlated with NTBs. To the extent that NTBs are trade barriers that raise import prices, the opposite correlation might be expected. Data problems may matter here. NTBs do not measure whether quantitative restrictions on trade bind, but rather whether governments have the option of imposing them.

\subsection{Additional Results and Robustness Checks for Imported-Input Demand}

Table 5 applies alternative estimators to our preferred specification in Table 4. Column (1) uses Tobit rather than OLS. In order to obtain consistent coefficient estimates (Wooldridge, 2002), we needed to reduce the number of fixed effects in the specification from a full set of parent-industry controls to a set of two-digit industry controls. Most coefficient estimates retain the same sign and pattern of significance - e.g., on trade costs and wages. The coefficient on capital is still positive but has become significantly so. This accords with the presumed complementarity between input processing and less-skilled labor discussed above, as there is substantial evidence in labor economics that capital and less-skilled labor are price substitutes.

\footnotetext{
19 A standard feature of EPZs is tariff breaks on inputs imported from abroad (for inputs used to produce exports). One might expect, then, that tariffs would have no impact on imported inputs in countries with EPZs. In unreported regressions we interacted the EPZ variable with trade costs to capture this effect but found the interactions to be insignificant.
} 
The coefficient estimate for output changes both sign and significance. As discussed in Section 2, there are concerns about the sensitivity of Tobit estimates to the included fixed effects. Nevertheless, the broad patterns appear match those of the OLS estimates.

The second column of Table 5 re-estimates our preferred specification where we replace our parent-industry dummy variables with a full set of country dummy variables. The cost of these country controls is the need to exclude all regressors that vary by country only. The benefit is that this checks whether estimates for the key trade-cost regressor are driven by unobserved, country-specific factors. The coefficient on trade costs is somewhat smaller in absolute value that in other specifications but remains statistically significant. The implied own-price elasticity from this country fixed-effects estimate is -2.82 (standard error of 0.97 ).

The third column of Table 5 uses an instrumental variables (IV) estimator. It is commonly asserted that multinationals have a large say in trade-policy formulation in host countries (e.g., Blonigen and Figlio, 1998) - especially small developing countries. If this were the case, then our negative correlation between trade costs and imported-input shares might reflect not the response of firms to exogenously given trade costs but rather the political-economy outcome of firms with vertical production networks lobbying successfully for low tariffs. To address this possibility we re-estimate our preferred specification instrumenting for trade costs with tariffs from 1989, five years before our sample. These earlier-period tariffs are valid instruments if they are correlated with current trade costs yet are uncorrelated with the disturbance term. Intuitively, we find it plausible that affiliate operations in 1994 have weak political-economy links with 1989 tariffs. Our IV estimates are qualitatively unchanged from the OLS estimates, with the coefficient on trade costs remaining significantly negative. ${ }^{20}$

\footnotetext{
20 An ex ante argument for discounting the endogeneity concern may be that actual estimation sample does not contain (due to data limitations discussed in Section 4.1) many very small countries where political influence of multinationals is likely to be
} 
Beyond what is reported in Table 4 and 5, we conducted a large number of other robustness checks. One set of checks involved alternative measures of key regressors and our regressand. We constructed industry tariffs and transportation costs using simple arithmetic rather than tradeweighted averages. We replaced statutory corporate tax rates with effective average corporate tax rates, reported in Grubert (2001) as constructed by the IRS Statistics of Income Division from tax returns of U.S. multinationals. We measured wages using affiliate data on average annual salaries for production (less-skilled) and non-production (more-skilled) workers (either for a given affiliate or for other affiliates in the same industry and country). And we also measured our regressand using inputs imported from U.S. parents only, excluding imports from unaffiliated U.S. third parties (see also note 14). Our estimation results were qualitatively unchanged by these and other measurement choices.

A second set of robustness checks involved sample restrictions. One was to exclude from our sample all affiliates in Mexico or Canada, to ensure that our findings were not driven by intra-NAFTA trade patterns. A second was to exclude affiliates facing very high hostcountry/industry tariffs. One might worry that the negative correlation between trade costs and imported-input intensity reflects tax evasion: in the face of high tariffs, firms might under-report the value of imported inputs to lower tax liabilities. For China-Hong Kong trade, Fisman and Wei (2001) find evidence of under-invoicing, but only at high tariff rates (i.e., above 35\%). We tried eliminating all observations of tariffs above various cut-offs, down to $20 \%$. Our estimation results were also qualitatively unchanged by these and other sampling choices.

strongest. The instruments used were three measures of 1989 industry-country tariffs, each of which used a different weighting scheme for aggregating the raw tariff data (see Data Appendix for details). The correlation between trade costs and our instruments is quite high: a regression of trade costs on the instruments obtained an R-squared of 0.60. We also note that instrumenting for trade costs may address measurement-error bias. Our analysis as formalized in equation (7) assumes that an affiliate classified in industry $\mathrm{X}$ based on the composition of its sales imports inputs in that same industry $\mathrm{X}$. In principle, this assumption need not be true: an industry-X affiliate may import inputs from another industry $Y$. In practice, the BEA has no 


\subsection{Export Behavior and the Determinants of Vertical Production Networks}

Consistent with theories of vertical FDI, we saw in Section 4.2 that affiliates with greater reliance on imported intermediate inputs also tend to be more export-intensive. Given this, we can gain additional insight on vertical production networks by examining export intensity. In the presence of vertical production networks, we would expect affiliate imports of inputs and affiliate exports to respond similarly to trade costs, factor prices, and other variables. To see whether this is the case, we replace the regressand $s_{\text {aipc }}^{\mathrm{m}}$ in equation (7) with the share of affiliate exports to the United States in affiliate revenues. Table 6 reports these final estimation results. The five specifications are our baseline and preferred OLS specifications from Table 4, and the Tobit, country fixed-effect, and IV specifications from Table 5.

Comparing columns 1 and 2 of Table 6 with columns 1 and 3 of Table 4, we see that every coefficient estimate except that on capital costs retains the same sign and often the same pattern of statistical significance. Like imported-input intensity, affiliate U.S.-export intensity is negatively correlated with host-country trade costs, less-skilled wages, and corporate taxes (in column 2), and positively correlated with high-skilled wages and the existence of EPZs. Comparing columns 3, 4, and 5 of Table 6 with columns 1, 2, and 3 of Table 5, we again see similar sign patterns and mostly similar patterns of statistical significance. In particular, trade costs are statistically significant for two of these three alternative specifications.

These results suggest that where affiliates are more specialized in processing inputs imported from the United States, they also export a higher fraction of their output to the United States. Lower trade costs, lower wages for less-skilled labor, and lower corporate tax rates are all

information on the industry composition of imported inputs for further processing. Note that because equation (7) conditions our analysis on affiliate output, we do not face measurement error due to using nominal rather than effective rates of protection. 
associated with stronger export orientation, just as they are associated with stronger import intensity. While the data do not permit us to say explicitly that the exports affiliates send to the United States are processed inputs imported from the United States, the results are consistent with this interpretation and with the general conclusion that vertical production networks shape trade patterns between U.S. parents and their foreign affiliates.

\section{Conclusion}

Distinguishing features of the most recent wave of globalization have been the rise of multinational firms and of trade in intermediate inputs. In this paper, we have examined the forces behind both these new developments by analyzing imports of inputs for further processing from U.S. multinational parents by their affiliates in foreign countries. These shipments of intermediate inputs provide a direct measure of vertical production networks in multinationals. Theory suggests that affiliate input processing depends on influences such as trade costs and factor prices. Our results support this prediction.

Among our main findings are that affiliate demand for imported inputs is higher is host countries with lower trade costs, lower wages for less-skilled labor (in absolute terms and relative to wages for more skilled labor), and lower corporate income tax rates. Demand for inputs is also affected by other host-country policies and characteristics, including the presence of export-processing zones and the size of the host-country market. Exports by affiliates exhibit similar patterns of correlation with trade costs, wages, and other variables.

Our finding of a high elasticity for trade costs is consistent with Yi (2003), who shows how trade in inputs allows small changes in tariffs to produce large changes in trade flows. Our findings contrast with much earlier empirical work on multinationals, which tended to find that the scale of activities by foreign affiliates of U.S. parent firms is larger in countries with higher 
wages and higher trade costs vis a vis the United States. Our results suggest that multinationals tailor their foreign operations to local market conditions. They appear to focus affiliates on processing imported inputs in countries where wages and trade costs are lower and markets are smaller; and they appear to focus affiliates on production for local consumers in countries where wages and trade costs are higher and markets are larger.

Our results also indicate that other host-country policies shape vertical production networks, sometimes in unexpected ways. Lower tax rates on corporate income are associated with greater affiliate input processing. While both theory and empirical work have shown that lower corporate taxes in a country are generally associated with greater FDI inflows, there has been little work on whether taxes affect how multinationals organize their foreign operations.

One final point is to re-emphasize what our analysis does and does not reveal about vertical production networks in multinational firms. We have focused on the decisions of these firms conditional on having a particular network of foreign affiliates. It would be interesting to extend this focus to the intertemporal decision of establishing and/or closing foreign affiliates, but that is beyond the scope of this paper. It would also be interesting to study vertical production networks in inter-firm arm's-length transactions. As we discussed, by construction the BEA data do not track such activities. But to the extent that these inter-firm dimensions of networks respond to the same incentives we have identified, our findings may apply more broadly. 


\section{Data Appendix}

\section{BEA Data}

The BEA data come from legally mandated confidential surveys it conducts. A U.S. multinational consists of one U.S. parent plus one or more foreign affiliates. A parent is a U.S. legal entity, such as a corporation, that generally controls a business enterprise located in the United States and that has at least one foreign affiliate. A foreign affiliate is a foreign business enterprise (incorporated or unincorporated) in which there is U.S. direct investment; that is, it is a foreign business enterprise in which the U.S. parent has at least a 10-percent equity stake. ${ }^{21}$ Firms responding to BEA surveys are instructed to denominate revenues and costs in U.S. dollars that are, for the most part, valued in the prices and exchange rates of the year covered by the data.

Industry of Affiliate: Each affiliate is classified in a single industry of primary business based on the distribution of sales across industries that it is required to report. For our 1994 data, the BEA uses an internal industry definition, the BEA International Surveys Industry (ISI) codes, which are closely related to the 1987 3-digit U.S. Standard Industrial Classification (SIC) codes. A foreign affiliate generally represents the consolidation of the U.S. direct investor's business operations in a host country in a single three-digit industry. ${ }^{22}$

Imported Intermediate Inputs for Further Processing: Our measure of imported inputs for further processing capture imports both from parent and non-parent U.S. entities. Approximately $90-95 \%$ of these imports are from parent firms. Even where affiliate imports come from an entity other than the parent, the parent may still have arranged the transaction. With this in mind, the measure of affiliate imports we use is all U.S. imports, including imports from parent and non-parent entities. Estimation results using just imports from parents are nearly identical to those we report. For affiliates belonging to small U.S. parents, the BEA imputes imports for further processing using data on total affiliate imports. Our results are robust to alternative imputation methods and to dropping affiliates with imputed data from the sample.

Wages: Manufacturing affiliates are required by the BEA to report wage bills and employment separately for non-production and production workers, a breakdown that tends to separate moreskilled from less-skilled workers. For each affiliate we construct wage unit values for nonproduction and production workers. In unreported results, we use these own-affiliate wage measures and also construct "outside" wage measures defined for each affiliate as the average wage paid by all other affiliates in the same country and industry. These outside wages may address the potential problem of endogeneity in affiliate-level wages, in that variation in affiliate wages may reflect variation both in true prices for given labor quality and in labor quality itself.

\footnotetext{
21 In this paper, we use the term affiliate or foreign affiliate to refer to this class of enterprises. Note that in the BEA data each affiliate is a business enterprise-different from other micro data sets on establishments, e.g., the U.S. Longitudinal Research Database. Enterprises may operate any number of establishments, information that the BEA does not track.

22 The only exception to this rule is that foreign affiliates in the same host country, but in different three-digit industries, may be consolidated if they are integral parts of the same business operation.
} 
Rental Price of Capital: The rental rate of capital is defined as an affiliate's return to capital (value added less employee compensation) over its fixed capital stock (net property, plant, and equipment) averaged over the 1985-1994 period (or, for affiliates established after 1985, from the affiliate's birth to 1994). Rental rates for a single year are highly volatile, and averaging over time helps smooth this series. In unreported regressions, endogeneity concerns lead us to try as an alternative measure the rental return to capital calculated for other affiliates in the same country and industry. Results for this measure are very similar to those that we report.

\section{Non-BEA Data}

Wages: Using data from the UNIDO Industry Database for 1994, we measure the unskilled wage as the average annual salary per worker in that country's apparel sector, which in most countries is the lowest-wage manufacturing industry. We measure the skilled wage as the average annual salary per worker in a country's chemical, electronics, and electrical machinery industries, which in most countries are the highest-wage, most skill-intensive industries.

Trade Barriers: Tariffs are from the United Nations' TRAINS (Trade Analysis and Information System) CD-ROM. The original source data are classified by country and by 6-digit Harmonized System product codes. ${ }^{23}$ Aggregation of the data from a 4-digit SIC basis to an ISI basis was obtained by weighting the disaggregated data by the value of U.S. exports to the country. Data on NTBs also come from TRAINS. The original source data for these were at the 4-digit SIC level, which we then concorded to BEA industries as just described. This information is categorical, indicating presence or absence of NTBs tracked by TRAINS.

The transportation-cost data were generated from data files in Feenstra (1996). For each observation we constructed transportation costs as charges for insurance and freight as a share of the customs value of imports. The original source data are classified on a 4-digit 1987 SIC basis; they were aggregated to an ISI basis by weighting the disaggregated data by the value of total U.S. exports to the host country. (We use exports and not imports to weight 4-digit transport costs since the freight rates we require are those that apply to inputs that the U.S. parent exports to its affiliates in a given country. Results using U.S. imports as weights to construct transport costs are very similar to those that we report.)

Other Variables: From PriceWaterhouseCoopers, we use an indicator for the presence of exportprocessing zones (EPZs) that captures a range of host-country export incentives. Using data from Shambaugh (2002), we also construct an indicator for whether the host country fixes the value of its currency to the U.S. dollar. Recent research (e.g., Frankel and Rose, 2002) finds that bilateral trade is stimulated by currency unions; we generalize from this evidence to examine whether host-country exchange-rate policy matters along the more-general fixed-versus-float margin. A final policy regressor is a collection of "economic freedom" measures collected by the Heritage Foundation and The Wall Street Journal. We average country index scores for respect for property rights, extent of government regulation, and prevalence of black-market activities, with higher scores indicating less economic freedom.

23 These data, plus a translation of them to a 1987 4-digit U.S. SIC basis were obtained from Jon Haveman. 


\section{References}

Adelman, Morris A. 1955. "Concept and Statistical Measurement of Vertical Integration," in Business Concentration and Price Policy. Princeton: Princeton University Press and NBER.

Barba Navaretti, Giorgio, Jan I. Haaland, and Anthony Venables. 2002. "Multinational Corporations and Global Production Networks: The Implications for Trade Policy." CEPR Report prepared for the European Commission Directorate General for Trade.

Blonigen, Bruce A., and David N. Figlio. 1998. "Voting for Protection: Does Direct Foreign Investment Influence Legislator Behavior?” American Economic Review, 88(4), September, pp. 1002-1014.

Blonigen, Bruce A., Ronald B. Davies, and Keith Head. 2002. "Estimating the Knowledge Capital Model of the Multinational Enterprise: Comment.” NBER Working Paper No. 8929.

Bordo, Michael, Barry Eichengreen, and Douglas Irwin. 1999. "Is Globalization Today Really Different from Globalization a Hundred Years Ago?" in Dani Rodrik and Susan Collins (eds.) Brookings Trade Forum 1999, pp. 1-50.

Borga, Maria and William Zeile. 2002. "Foreign Outsourcing and the Intrafirm Trade of U.S. Multinational Companies." Mimeo, U.S. Bureau of Economic Analysis.

Brainard, Lael. 1997. "An Empirical Assessment of the Proximity-Concentration Tradeoff between Multinational Sales and Trade." American Economic Review 87: 520-544.

Campa, Jose, and Linda Goldberg. 1997. "The Evolving External Orientation of Manufacturing: a Profile of Four Countries." Federal Reserve Bank of New York Economic Policy Review, July, pp. 53-81.

Carr, David L., James R. Markusen, and Keith E. Maskus. 2001. "Estimating the Knowledge-Capital Model of the Multinational Enterprise.” American Economic Review, 91, pp. 693-708.

Clausing, Kimberly A. 2001. “The Impact of Transfer Pricing on Intrafirm Trade.” In James R. Hines (ed.) International Taxation and Multinational Activity. Chicago: University of Chicago Press.

Council on Foreign Relations. 2002. America-Still Unprepared, Still in Danger. New York: Council on Foreign Relations.

Diewert, W. Erwin. 1974. "Applications of Duality Theory," in M. Intriligator and D. Kendrick (eds.) Frontiers of Quantitative Economics Volume II, Amsterdam: North-Holland, pp. 106-171.

Ekholm, Karolina, Rikard Forslid, and James R. Markusen. 2003. "Export-Platform Foreign Direct Investment." National Bureau of Economic Research Working Paper No. 9517.

Feenstra, Robert C. 1996. "U.S. Imports: Data and Concordances." National Bureau of Economic Research Working Paper \#5515, plus data CD-ROM (http://www.nber.org).

Feenstra, Robert C. 1998. "The Integration of Trade and the Disintegration of Production." Journal of Economic Perspectives, Vol.12 (4), Fall, pp. 31-50. 
Feenstra, Robert C., and Gordon H. Hanson. 2002. "Global Production Sharing and Rising Inequality: A Survey of Trade and Wages." In James Harrigan, ed., Handbook of International Trade, Basil Blackwell, forthcoming.

Feinberg, Susan E., and Michael P. Keane. 2001. "U.S.-Canada Trade Liberalization and MNC Production Location." Review of Economics and Statistics, 83(1), February, pp. 118-132.

Fisman, Raymond, and Shang-Jin Wei. 2001. "Tax Rates and Tax Evasion: Evidence from 'Missing Imports' in China. National Bureau of Economic Research Working Paper No. 8551.

Frankel, Jeffrey, and Andrew Rose. 2002. "An Estimate of the Effect of Common Currencies on Trade and Income.” Quarterly Journal of Economics, 117, pp. 437-466.

Grossman, Gene and Elhanan Helpman. 2002a. "Outsourcing in a Global Economy." National Bureau of Economic Research Working Paper No. 8728.

Grossman, Gene and Elhanan Helpman. 2002b. "Managerial Incentives and the International Organization of Production." National Bureau of Economic Research Working Paper No. 9403.

Grubert, Harry. 2001. "Tax Planning by Companies and Tax Competition by Governments: Is There Evidence of Changes in Behavior?" In James R. Hines, Jr. (ed.) International Taxation and Multinational Activity, Chicago: University of Chicago Press, forthcoming.

Grubert, Harry, and J. Mutti. 1991. "Taxes, Tariffs, and Transfer Pricing in Multinational Corporation Decision Making." Review of Economics and Statistics 17, pp. 285-293.

Hanson, Gordon H. 2001. "Should Foreign Countries Promote Foreign Direct Investment?" G-24 Discussion Paper Series, No. 9.

Hanson, Gordon H., Raymond J. Mataloni, Jr., and Matthew J. Slaughter. 2001. "Expansion Strategies of U.S. Multinational Firms," in D. Rodrik and S. Collins (eds.) Brookings Trade Forum, pp. 245-294.

Hanson, Gordon H. and Chong Xiang. 2002. "The Home-Market Effect and Bilateral Trade Patterns." NBER Working Paper No. 9076.

Haskel, Jonathan E., Sonia Pereira, and Matthew J. Slaughter. 2002. "Does Inward Foreign Direct Investment Boost the Productivity of Domestic Firms?" NBER Working Paper No.8724.

Helpman, Elhanan. 1984. "A Simple Theory of Trade with Multinational Corporations." Journal of Political Economy, 92, pp. 451-471.

Helpman, Elhanan, and Paul R. Krugman. 1985. Market Structure and Foreign Trade. Cambridge, MA: MIT Press.

Helpman, Elhanan, Marc Melitz, and Stephen R. Yeaple. 2003. "Exports versus FDI." National Bureau of Economic Research Working Paper No. 9439.

Hines, James R. (ed.). 2001. International Taxation and Multinational Activity. Chicago: University of Chicago Press. 
Hummels, David, Jun Ishii, and Kei-Mu Yi. 2001. "The Nature and Growth of Vertical Specialization in World Trade." Journal of International Economics, Vol. 54, pp. 75-96.

Kohli, Ulrich R. 1978. "A Gross National Product Function and the Derived Demand for Imports and Supply of Exports.” Canadian Journal of Economics, 11, pp. 167-82.

Kohli, Ulrich R. 1991. Technology, Duality and Foreign Trade, London: Harvester Whetsheaf.

Kumar, Nagesh. 1994. "Determinants of Export Orientation of Foreign Production by U.S. Multinationals: An Inter-Country Analysis.” Journal of International Business Studies (1), pp. 141-156.

Markusen, James R. 2002. Multinational Firms and the Theory of International Trade. Cambridge, MA: MIT Press.

Markusen, James R. and Keith Maskus. 1999. "Discriminating among Alternative Theories of the Multinational Enterprise.” National Bureau of Economic Research Working Paper No. 7164.

Markusen, James R. and Keith Maskus. 2001. "Multinational Firms: Reconciling Theory and Evidence." In Magnus Blomstrom and Linda Goldberg (eds.) Topics in International Economics: $A$ Festschrift in Honor of Robert E. Lipsey. Chicago: University of Chicago Press, pp. 71-95.

Markusen, James R., and Anthony Venables. 2000. "The Theory of Endowment, Intra-Industry and Multinational Trade." Journal of International Economics, 52, pp. 209-234.

Sansing, Richard. 1999. "Relationship-Specific Investments and the Transfer Pricing Paradox." Review of Accounting Studies, 4, pp. 119-134.

Shambaugh, Jay C. 2002. "The Effects of Fixed Exchange Rates on Monetary Policy.” Mimeo.

Shatz, Howard J. 2000. "U.S. Multinational Exports From Developing Countries." Chapter 3 in The Location of U.S. Multinational Affiliates. Harvard University Ph.D. Dissertation.

Slaughter, Matthew J. 2000. "Production Transfer Within Multinational Enterprises and American Wages," Journal of International Economics, 50, April, pp. 449-472.

U.S. Bureau of Economic Analysis. 2002. U.S. Direct Investment Abroad: Preliminary Results From the 1999 Benchmark Survey. Washington, DC: U.S. Government Printing Office.

Wooldridge, Jeffrey M. 2002. Econometric Analysis of Cross Section and Panel Data. Cambridge: MIT Press.

Yeaple, Stephen R. 2001. "The Determinants of U.S. Outward Foreign Direct Investment: Market Access versus Comparative Advantage." Mimeo, University of Pennsylvania.

Yeats, Alexander J. 2001. "Just How Big is Global Production Sharing?" in Sven W. Arndt and Henryk Kierzkowski (eds.), Fragmentation: New Production Patterns in the World Economy, Oxford: Oxford University Press.

Yi, Kei-Mu. 2003. "Can Vertical Specialization Explain the Growth of World Trade?" Journal of Political Economy, 111(1), pp. 52-102. 
Table 1: Summary Statistics

\begin{tabular}{cc}
\hline Variable & Mean (s.d.) \\
\hline Imported-Input Share & 0.110 \\
& $(0.176)$ \\
More-Skilled Wages & 28.631 \\
(\$, Thousands) & $(17.089)$ \\
Less-Skilled Wages & 14.811 \\
(\$, Thousands) & $(7.897)$ \\
Tariff Rate & 0.054 \\
(ad valorem) & $(0.051)$ \\
Transportation Costs & 0.045 \\
(ad valorem) & $(0.038)$ \\
Trade Costs & 0.099 \\
(ad valorem) & $(0.071)$ \\
Corporate Tax Rate & 0.344 \\
& $(0.056)$ \\
Adjacent to United States & 0.176 \\
& $(0.380)$ \\
English Speaking & 0.317 \\
No. Observations & $(0.465)$ \\
& 4,102 \\
\hline
\end{tabular}

Notes: Each cell reports the variable mean and, in parentheses, its standard deviation. These statistics are for the sample used in the baseline estimates reported in Table 4; the year of these data is 1994. See text for details on variable definitions and construction.

Source: Authors' calculations using data from the U.S. Bureau of Economic Analysis and other sources. 
Table 2: Affiliate Imported Intermediate Inputs, by Industry and Region, 1994

\begin{tabular}{|c|c|c|c|c|c|c|c|c|c|c|}
\hline $\begin{array}{l}\text { Region } \\
\text { Industry }\end{array}$ & Canada & Mexico & $\begin{array}{c}\text { Other } \\
\text { Lat.Am. }\end{array}$ & $\begin{array}{l}\text { OECD } \\
\text { Europe }\end{array}$ & $\begin{array}{l}\text { OECD } \\
\text { Asia } \\
\end{array}$ & $\begin{array}{l}\text { East } \\
\text { Asia }\end{array}$ & $\begin{array}{l}\text { Other } \\
\text { Asia }\end{array}$ & Africa & $\begin{array}{c}\text { Middle } \\
\text { East }\end{array}$ & World \\
\hline Chemicals & 18.92 & 12.35 & 9.44 & 4.90 & 9.87 & 15.51 & 8.57 & -- & -- & 7.62 \\
\hline Metals & 19.23 & 23.13 & -- & -- & 7.88 & 13.79 & -- & 15.51 & 4.14 & 8.24 \\
\hline Machinery & 37.19 & 44.24 & 9.95 & 8.20 & 7.42 & 8.62 & 6.06 & 4.79 & 10.98 & 10.98 \\
\hline Electronics & 20.16 & 40.82 & 21.14 & 9.83 & 17.89 & 26.98 & 1.49 & 13.34 & 4.39 & 17.44 \\
\hline Transportation & 50.36 & 45.67 & 3.36 & 2.33 & 5.11 & 6.21 & -- & -- & -- & 21.39 \\
\hline Other Mfg & 18.15 & 13.29 & -- & -- & 11.82 & 7.27 & -- & 2.33 & 8.89 & 8.89 \\
\hline Total & 38.66 & 36.70 & 8.45 & 5.64 & 10.41 & 15.24 & 4.46 & 11.79 & 4.48 & 13.59 \\
\hline
\end{tabular}

Notes: This table shows means by two-digit industry and geographic region of the share of imported inputs for further processing in total revenues for foreign affiliates of U.S. multinational enterprises. Means are weighted by affiliate total revenue. The "Other Europe" region is excluded from the table due to disclosure restrictions (there are few affiliates per industry in the region). The same applies to entries that read, "--." The sample is 4,285 majority-owned foreign affiliates of U.S. multinationals that belong to a parent that has as least two foreign affiliates. The year is 1994 .

Source: Authors' calculations using data from the U.S. Bureau of Economic Analysis. 
Table 3: Affiliate Exports to the United States, by Industry and Region, 1994

\begin{tabular}{cccccccc}
\hline \hline $\begin{array}{c}\text { Region } \\
\text { Industry }\end{array}$ & Canada & Mexico & $\begin{array}{c}\text { Other } \\
\text { Lat.Am. }\end{array}$ & $\begin{array}{c}\text { OECD } \\
\text { Europe }\end{array}$ & $\begin{array}{c}\text { OECD } \\
\text { Asia }\end{array}$ & $\begin{array}{c}\text { East } \\
\text { Asia }\end{array}$ & World \\
\hline Chemicals & 18.96 & 2.05 & 2.71 & 3.64 & 2.76 & 0.77 & 4.82 \\
Metals & 40.86 & 11.76 & 5.71 & 3.44 & 2.73 & 6.19 & 10.29 \\
Machinery & -- & 29.32 & 17.60 & 7.63 & -- & 52.72 & 20.19 \\
Electronics & 24.04 & 53.76 & -- & 6.14 & 5.52 & 26.55 & 16.16 \\
Transportation & 61.40 & 54.80 & 2.33 & 4.10 & 1.73 & 6.80 & 26.45 \\
Other Mfg & 26.96 & 13.64 & 5.24 & 4.01 & 3.02 & 4.36 & 6.95 \\
Total & 47.91 & 40.84 & 6.18 & 4.90 & 6.62 & 32.85 & 16.05 \\
\hline
\end{tabular}

Notes: This table shows means by two-digit industry and geographic region of the share of exports to the United States in total revenues for foreign affiliates of U.S. multinational enterprises. Means are weighted by affiliate total sales. Four regions are excluded from the table due to disclosure restrictions (there are few affiliates per industry in the region): Other Europe, Other Asia, Africa, and the Middle East. The same applies to entries that read, "--." The sample is 4,285 majority-owned foreign affiliates of U.S. multinationals that belong to a parent that has as least two foreign affiliates. The year is 1994 .

Source: Authors' calculations using data from the U.S. Bureau of Economic Analysis. 
Table 4: Baseline Estimation Results for Imported Intermediate Inputs

\begin{tabular}{cccc}
\hline \hline Regressor & $(1)$ & $(2)$ & $(3)$ \\
\hline More-Skilled Wages & 0.007 & 0.027 & 0.028 \\
& $(0.011)$ & $(0.010)^{* *}$ & $(0.010)^{* *}$ \\
Less-Skilled Wages & -0.046 & -0.046 & -0.045 \\
Capital Rental Rate & $(0.010)^{* *}$ & $(0.011)^{* *}$ & $(0.009)^{* *}$ \\
& 0.003 & 0.001 & 0.001 \\
$(1+$ Trade Costs) & $(0.006)$ & $(0.005)$ & $(0.005)$ \\
& -0.640 & -0.333 & -0.262 \\
$(1$ - Corporate Tax Rate) & $(0.080)^{* *}$ & $(0.089)^{* *}$ & $(0.078)^{* *}$ \\
Output & 0.009 & 0.028 & 0.044 \\
Adjacent to United States & $(0.031)$ & $(0.029)$ & $(0.028)$ \\
& -0.008 & -0.007 & -0.007 \\
Export-Processing Zone & $(0.004)^{*}$ & $(0.004)$ & $(0.004)$ \\
& & 0.126 & 0.126 \\
Non-Tariff Barriers & & $(0.014)^{* *}$ & $(0.013)^{* *}$ \\
Host-Market Size & 0.043 & 0.048 \\
Economic Freedom & & $(0.015)^{* *}$ & $(0.015)^{* *}$ \\
& & 0.020 & 0.021 \\
& & $(0.012)$ & $(0.012)$ \\
& & -0.043 & -0.045 \\
& & $(0.010)^{* *}$ & $(0.008)^{* *}$ \\
& & -0.037 & -0.040 \\
& & $(0.009)^{* *}$ & $(0.006)^{* *}$ \\
\hline
\end{tabular}

Notes: See continuation of this table on next page. 


\section{Table 4: Baseline Estimation Results (Continued)}

\begin{tabular}{cccc}
\hline Regressor & $(1)$ & $(2)$ & $(3)$ \\
\hline English Speaking & & -0.006 & \\
& $(0.009)$ & \\
(1- Value-Added Tax Rate) & 0.029 & \\
Fixed Exchange Rate w/ U.S. & $(0.046)$ & \\
& & 0.021 & \\
FDI Openness & $(0.015)$ & \\
& & -0.001 & \\
U.S. Materials Share of Sales & & $0.006)$ & \\
& & 0.075 & \\
Controls & $(0.051)$ & \\
No. Observations & 4,102 & 4,102 & 4,102 \\
Adjusted R-Squared & 0.40 & 0.48 & 0.48 \\
\hline
\end{tabular}

Notes: Each column of this table estimates a specification of equation (7) using the regressors of that column. The dependent variable is imported intermediate inputs for further processing from the United States as a share of affiliate total revenues (plus inventory changes). Cell entries are OLS parameter estimates (and standard errors that allow for both arbitrary forms of heteroskedasticity and correlations in disturbances within parent-industry groups). * indicates that a parameter estimate is different from zero at the 5\% significance level; ** at the $1 \%$ level. All specifications also include 777 parent-by-industry dummy variables. All regressors in column (1), as well as Host-Market Size, (1- ValueAdded Tax Rate), and U.S. Materials Share of Sales, are in logarithms. See text for equation (7) and details on variable definitions and construction. 
Table 5: Estimation Results, Alternative Estimators

\begin{tabular}{|c|c|c|c|}
\hline Regressor & (1) & (2) & (3) \\
\hline \multirow[t]{2}{*}{ More-Skilled Wages } & 0.068 & & 0.033 \\
\hline & $(0.013)^{* *}$ & & $(0.009)^{* *}$ \\
\hline \multirow[t]{2}{*}{ Less-Skilled Wages } & -0.097 & & -0.050 \\
\hline & $(0.013)^{* *}$ & & $(0.009)^{* *}$ \\
\hline \multirow[t]{2}{*}{ Capital Rental Rate } & 0.010 & 0.001 & 0.002 \\
\hline & $(0.005)^{*}$ & $(0.005)$ & $(0.004)$ \\
\hline \multirow[t]{2}{*}{$(1+$ Trade Costs $)$} & -0.359 & -0.211 & -0.360 \\
\hline & $(0.089)^{* *}$ & $(0.107)^{*}$ & $(0.182)^{*}$ \\
\hline \multirow[t]{2}{*}{ (1-Corporate Tax Rate) } & 0.032 & & 0.076 \\
\hline & $(0.051)$ & & $(0.036)^{*}$ \\
\hline \multirow[t]{2}{*}{ Output } & 0.008 & -0.007 & -0.007 \\
\hline & $(0.003)^{* *}$ & $(0.004)$ & $(0.002)^{* *}$ \\
\hline \multirow[t]{2}{*}{ Adjacent to United States } & 0.133 & & 0.123 \\
\hline & $(0.012)^{* *}$ & & $(0.014)^{* *}$ \\
\hline \multirow[t]{2}{*}{ Export-Processing Zone } & 0.089 & & 0.049 \\
\hline & $(0.015)^{* *}$ & & $(0.014)^{* *}$ \\
\hline \multirow[t]{2}{*}{ Non-Tariff Barriers } & 0.020 & 0.025 & 0.023 \\
\hline & $(0.011)$ & $(0.014)$ & $(0.008)^{* *}$ \\
\hline \multirow[t]{2}{*}{ Host-Market Size } & -0.086 & & -0.044 \\
\hline & $(0.010)^{* *}$ & & $(0.007)^{* *}$ \\
\hline \multirow[t]{2}{*}{ Economic Freedom } & -0.079 & & -0.038 \\
\hline & $(0.008)^{* *}$ & & $(0.007)^{* *}$ \\
\hline Estimator & Tobit & OLS & IV \\
\hline Controls & Industry & Country & Parent-Industry \\
\hline No. of Observations & 4,102 & 4,102 & 3,977 \\
\hline Adjusted R-Squared & & 0.49 & \\
\hline
\end{tabular}

Notes: Each column of this table estimates our preferred specification of equation (7) using the estimator and controls indicated. The dependent variable is imported intermediate inputs for further processing from the United States as a share of affiliate total revenues (plus inventory changes). Cell entries are parameter estimates (and standard errors that allow for both arbitrary forms of heteroskedasticity and correlations in disturbances within parent-industry groups). * indicates that a parameter estimate is different from zero at the $5 \%$ significance level; $* *$ at the $1 \%$ level. See text for equation (7) and details on variable definitions and construction. 
Table 6: Estimation Results, Export-Intensity Regressand

\begin{tabular}{|c|c|c|c|c|c|}
\hline Regressor & (1) & (2) & (3) & (4) & (5) \\
\hline \multirow[t]{2}{*}{ More-Skilled Wages } & 0.003 & 0.014 & 0.038 & & 0.015 \\
\hline & $(0.010)$ & $(0.010)$ & $(0.019)^{*}$ & & $(0.010)$ \\
\hline \multirow[t]{2}{*}{ Less-Skilled Wages } & -0.042 & -0.020 & -0.087 & & -0.023 \\
\hline & $(0.010)^{* *}$ & $(0.009)^{*}$ & $(0.020)^{* *}$ & & $(0.011)^{*}$ \\
\hline \multirow[t]{2}{*}{ Capital Rental Rate } & -0.019 & -0.020 & -0.056 & -0.021 & -0.021 \\
\hline & $(0.005)^{* *}$ & $(0.005)^{* *}$ & $(0.008)^{* *}$ & $(0.005)^{* *}$ & $(0.004)^{* *}$ \\
\hline \multirow[t]{2}{*}{$(1+$ Trade Costs $)$} & -0.583 & -0.222 & -0.719 & -0.222 & -0.307 \\
\hline & $(0.113)^{* *}$ & $(0.123)$ & $(0.140)^{* *}$ & $(0.152)$ & $(0.116)^{* *}$ \\
\hline \multirow[t]{2}{*}{$(1-$ Corporate Tax Rate $)$} & -0.006 & 0.093 & 0.201 & & 0.092 \\
\hline & $(0.035)$ & $(0.034)^{* *}$ & $(0.075)^{* *}$ & & $(0.042)^{* *}$ \\
\hline \multirow[t]{2}{*}{ Output } & -0.003 & -0.001 & 0.047 & -0.001 & -0.001 \\
\hline & $(0.005)$ & $(0.004)$ & $(0.004)^{* *}$ & $(0.005)$ & $(0.003)$ \\
\hline \multirow[t]{2}{*}{ Adjacent to United States } & & 0.143 & 0.217 & & 0.138 \\
\hline & & $(0.015)^{* *}$ & $(0.017)^{* *}$ & & $(0.012)^{* *}$ \\
\hline \multirow[t]{2}{*}{ Export-Processing Zone } & & 0.057 & 0.139 & & 0.059 \\
\hline & & $(0.023)^{*}$ & $(0.023)^{* *}$ & & $(0.014)^{* *}$ \\
\hline \multirow[t]{2}{*}{ Non-Tariff Barriers } & & 0.016 & 0.011 & 0.021 & 0.013 \\
\hline & & $(0.018)$ & $(0.018)$ & $(0.021)$ & $(0.010)$ \\
\hline \multirow[t]{2}{*}{ Host-Market Size } & & -0.015 & 0.004 & & -0.016 \\
\hline & & $(0.008)$ & $(0.016)$ & & $(0.008)^{*}$ \\
\hline \multirow[t]{2}{*}{ Economic Freedom } & & -0.011 & -0.045 & & -0.009 \\
\hline & & $(0.007)$ & $(0.013)^{* *}$ & & $(0.007)$ \\
\hline Estimator & OLS & OLS & Tobit & OLS & IV \\
\hline Controls & Parent-Ind. & Parent-Ind. & Industry & Country & Parent-Ind \\
\hline No. of Observations & 4,102 & 4,102 & 4,102 & 4,085 & 4,102 \\
\hline Adjusted R-Squared & 0.48 & 0.54 & & 0.55 & \\
\hline
\end{tabular}

Notes: Each column of this table estimates a specification of equation (7) replacing equation (7)'s regressand with the share of affiliate sales accounted for by exports to the United States. Each specification uses the estimator and controls indicated. Cell entries are parameter estimates (and standard errors that allow for both arbitrary forms of heteroskedasticity and correlations in disturbances within parent-industry groups). * indicates that a parameter estimate is different from zero at the $5 \%$ significance level; ** at the $1 \%$ level. See text for equation (7) and details on variable definitions and construction. 